\title{
Evaluation of programmed cell death processes on the lens epithelium of older dogs with diabetic and hypermature cataracts
}

\author{
Avaliação dos processos de morte celular programada \\ no epitélio da lente de cães idosos com catarata diabética \\ e hipermadura
}

\author{
Ana Paula HVENEGAARD ${ }^{1}$; Paulo Sergio de Moraes BARROS ${ }^{1}$; Angélica Mendonça Vaz SAFATLE \\ Michelle Barbosa Pereira BRAGA-SÁ ${ }^{1}$; Luana Vicente MELO ${ }^{2}$; Ana Carolina SANTANA²; \\ Bryan Hudson HOSSY3; Nadia Campos de Oliveira MIGUEL ${ }^{2}$
}

\begin{abstract}
${ }^{1}$ Universidade de São Paulo, Faculdade de Medicina Veterinária e Zootecnia, Serviço de Oftalmologia, São Paulo - SP, Brazil ${ }^{2}$ Universidade Federal do Rio de Janeiro, Instituto de Ciências Biomédica, Programa de Desenvolvimento Celular, Rio de Janeiro - RJ, Brazil ${ }^{3}$ Universidade Federal do Rio de Janeiro, Clínica Médica, Serviço de Dermatologia, Rio de Janeiro - RJ, Brazil
\end{abstract}

\begin{abstract}
It is well known that posterior capsule opacification (PCO), one of the most common late postoperative complications of cataract surgery, is mainly caused by proliferation and differentiation of remaining lens epithelial cells (LECs) on the posterior lens capsule. Many authors suggest that alterations induced by the pathophysiology of cataracts, its metabolism and the use of $0.1 \%$ trypan blue (TB) must cause some degree of cellular damage on these cells, wicht would help to prevent and/or reduce the incidence of PCO after cataract surgery in humans. Therefore, the aim of this study was to evaluate the expression of cell death markers on LECs of older dogs with diabetic and hypermature cataracts, after capsulorhexis, both using $0.1 \%$ TB. Twenty samples collected from 13 dogs of different breeds, with ages varying from 8 to 12 years-old, with diabetic and hypermature cataracts, which had been subjected to phacoemulsification surgery (Phaco) using $0.1 \%$ TB for staining were studied. Animals were classified as dogs with diabetic (DC) and hypermature cataracts (HC), and expression of molecular markers for apoptosis and autophagy (caspase-3 and beclin-1) on LECs were obtained by immunofluorescence technique. The expression of caspase-3 and beclin-1 was observed in every studied sample and did not differ between groups. In conclusion, our findings suggest that apoptosis and autophagy processes occur to LECs in older dogs presenting diabetic and hypermature cataracts after Phaco utilizing 0.1\% TB. Our results may be helpful to future studies of PCO in post-phacoemulsification surgery patients.
\end{abstract}

Keywords: Cataracts. Diabetes. Apoptosis. Autophagy. Lens epithelium cells.

\section{Resumo}

A opacificação da cápsula posterior da lente do globo ocular é a complicação mais observada após a remoção da lente. Essa patologia é causada principalmente pela proliferação e diferenciação das células do epitélio anterior da lente em sua cápsula posterior. Muitos autores sugerem que alterações induzidas pelo metabolismo e/ou patofisiologia da catarata e o uso do corante de azul de tripan a 0,1\% devam causar algum dano a essas células, o que supostamente ajudaria a prevenir e reduzir a incidência de tal complicação em humanos. Este trabalho avaliou a expressão de marcadores de morte celular no epitélio anterior da lente de cães idosos com catarata diabética e hipermadura, após capsulorrexe realizada com o emprego do azul de tripan a $0,1 \%$. Foram estudadas vinte amostras colhidas de treze cães de diferentes raças, com idades variando de oito a doze anos, que apresentavam catarata diabética ou hipermadura e que foram submetidos à facoemulsificação utilizando corante de azul de tripan a $0,1 \%$. Foram designados dois grupos: com catarata diabética (DC) e com catarata hipermadura (HC). A expressão molecular dos marcadores de morte celular por apoptose a autofagia (caspase-3 e beclina-1) no epitélio anterior da lente foi avaliada pela técnica de imunofluorescência. Observou-se que a expressão de caspase-3 e beclina-1 ocorreu em todas as amostras e não foi diferente entre os grupos. Os achados deste estudo sugerem que o processo de morte celular por apoptose e autofagia ocorre no epitélio anterior da lente de cães idosos com catarata diabética e hipermadura submetidos à facoemulsificação com o corante de azul de tripan a $0,1 \%$. Este resultado pode ser útil para estudos futuros da opacidade da cápsula posterior da lente em cães submetidos à facoemulsificação.

Palavras-chave: Catarata. Diabetes. Apoptose. Autofagia. Epitélio anterior da lente. 
Correspondence to:

Ana Paula Hvenegaard

Universidade de São Paulo, Faculdade de Medicina Veterinária

e Zootecnia, Serviço de Oftalmologia

Av. Prof. Orlando Marques de Paiva, 87 - Cidade Universitária

CEP 05508-270, São Paulo, SP, Brazil

e-mail: ana6113@usp.br

Received: 15/6/2017

Approved: 1/12/2017

\section{Introduction}

Cataracts are one of the most frequent causes of blindness in diabetic and non-diabetic human patients and dogs (GLOVER; CONSTANTINESCU, 1997; KIM et al., 2012; ABDELKADER et al., 2015). In almost 75\% of dogs, diabetic cataracts are complete, bilateral, aggressive, and of sudden onset. This type of cataract can develop within the first year of the disease and its formation is independent of insulin administration (BASHER; ROBERTS, 1995; BEAM et al., 1999). The pathophysiology of diabetic cataracts in dogs is well-defined and is based on a series of events related to changes in metabolic pumps, protein and ion concentrations and antioxidant activity on the anterior capsule and its lens epithelial cells (LECs) (BASHER; ROBERTS, 1995; GLOVER; CONSTANTINESCU, 1997).

As opposed to diabetic cataracts, the etiology of spontaneous cataracts is undefined in dogs, as rates of prevalence and speed of development are still unknown. Hypermature cataracts are the most evolved stage of this cataract type (SLATTER, 2005), which is frequently diagnosed in human patients and dogs from developing countries, such as India (VENKATESH et al., 2010) and Brazil, where economic constraints and unequal distribution of eye care facilities are a common issue that accounts for late presentation for cataract surgery (KHANNA et al., 2011).

Phacoemulsification surgery (Phaco) has been the preferred surgical technique for cataract removal and trypan blue solution (TB) the most widely utilized capsular dye for staining the anterior lens capsule (GLOVER; CONSTANTINESCU, 1997; GELATT; GELATT, 2001). Although advantages and safety of its use was proposed by Wollensak et al., 2004; Chang et al., 2005; Ozturk; Osher, 2006; and Dick et al., 2008, other investigations found that some ocular structures may get damaged, such as the posterior segment (KODJIKIAN et al., 2005) and the LECs, in which decreased density and viability of cells were observed in human patients submitted to the stain (NANAVATY et al., 2006; PORTES et al., 2010).
Posterior capsule opacification (PCO), one of the most common late postoperative complications of cataract surgery is observed in both species (NANAVATY et al., 2006; SIGLE; NASISSE, 2006). In dogs, it affects almost $68 \%$ of diabetics and $67 \%$ of nondiabetics after Phaco (BAGLEY II; LAVACH, 1994). Causes for PCO formation include capsular fibrosis, surgical techniques and/or trauma itself, but mainly proliferation and differentiation of remaining LECs on the posterior lens capsule (GLOVER; CONSTANTINESCU, 1997; BRAS et al., 2006; WORMSTONE et al., 2009; JOSHI, 2013; TIWARI et al., 2015). Many authors suggest that alterations induced by the pathophysiology of cataracts, its metabolism, and the use of $0.1 \%$ TB stain on LECs may help to prevent and/or reduce the incidence of PCO after cataract surgery in humans (NANAVATY et al., 2006; PORTES et al., 2007; PORTES et al., 2010; KIM et al., 2012; JUNG et al., 2013). The presente investigation evaluated the expression of cell death markers on LECs of older dogs with aggressive and high-risk cataracts, such as diabetic and hypermature types, after Phaco utilizing $0.1 \%$ TB as stain.

\section{Materials and Methods}

\section{Ethical statement}

Approval for this study was obtained from the Ethics Committee in the Use of Animals of the Faculty of Veterinary Medicine and Animal Science of the University of São Paulo, Brazil (n. 2.964/2013).

\section{Animals}

Recruited animals included 8- to 12-year-old male and female dogs of different breeds with diabetic and hypermature cataracts, which had been subjected to Phaco using $0.1 \%$ TB for staining the anterior lens capsule. Dogs were grouped by cataract type: diabetic cataracts (DC) and hypermature cataracts (HC). Relevant data on diabetes mellitus and studied cataracts were recorded.

Animals which had ocular and systemic diseases other than diabetes, hypermature and diabetic cataracts diagnosed between the first day of consultation and the day of surgery, were excluded from the study.

\section{Surgical technique}

All phacoemulsification surgeries were performed by the same surgeon (A.M.V.S.). Before capsulorhexis, dogs received injections of 10 units of TB $0.1 \%$ (Azul de Tripan 
0.1\% ${ }^{\circledR}$, Ophthalmos Ind. Farmacêutica, São Paulo, SP, Brazil) solution diluted with 20 units of air. Injections were made into the anterior chambers (through a $0.9 \mathrm{~mm}$ dorsal paracentesis), where the stain remained for $1 \mathrm{~min}$. After that, a 2.0\% methylcellulose solution was injected to remove excess TB from the chamber. Anterior lens capsules and their epithelia were collected with utrata capsulorhexis forceps using the continuous curvilinear capsulorhexis method. Samples were immediately fixed with $10 \%$ formaldehyde solution. Immunofluorescence technique was utilized to evaluate the molecular expression of programmed cell death processes (apoptosis and autophagy) in every studied sample.

\section{Immunofluorescence technique}

Samples were first rinsed, dehydrated at increasing ethanol concentrations, bleached in xylene and embedded in paraffin. Next, $5.0 \mu \mathrm{m}$ sections were cut and mounted on poly-L-lysine-coated slides. For immune detection, sections were deparaffinized, cleared three times in xylene for $5 \mathrm{~min}$, dehydrated in a graded ethanol series, rinsed twice with distilled water for $5 \mathrm{~min}$ and immersed in $10 \mathrm{ml}$ of sodium citrate solution ( $\mathrm{pH}$ 6.0). After that, for antigen recovery, slides were heated in a microwave oven for $2 \mathrm{~min}$ at power 10 and cooled at room temperature for $60 \mathrm{~min}$ in a blocking solution (10\% bovine serum albumin - BSA), diluted in PBS. After blocking, sections were incubated with primary polyclonal antibodies (rabbit anti-caspase-3 and rabbit anti-beclin-1) (Merck Millipore Headquarters, Billerica, MA, USA) and kept overnight in a wet chamber at approximately $4^{\circ} \mathrm{C}$. The next day, slides were washed three times for 5 min with PBS. Samples were processed by incubating for $2 \mathrm{~h}$ with the specific fluorescent ( $\alpha$ goat anti-rabbit) secondary antibody (Alexa 488, Life Technologies do Brazil Ltda., São Paulo, SP, Brazil), in PBS/triton, in the dark and at room temperature. After that, diamidino-2-phenylindole hydrochloride (Dapi) staining (Sigma, St. Louis, MO, USA) was added for nuclei exposure. Slides were then washed in distilled water and, finally, mounted in the dark on fluoromount (Fluoromount ${ }^{\circledR}$ Aqueous
Mounting Medium, Sigma - Aldrich Co., Saint Louis, MO, USA). Negative control sections were also processed in the absence of primary antibodies (data not shown). All samples were examined under a confocal microscope (Zeiss META 510, Carl Zeiss, Baltimore, MD, USA).

\section{Analysis techniques}

A light microscope was used for analysis. Five photomicrographs from each sample were taken and analyzed with Image Pro Plus software (Cybernetics, Image-pro plus, Media Cybernetics, Inc., Rockville, MD, USA). In this analysis, the fluorescence of antibodies for apoptosis and autophagy (caspase- 3 and beclin-1) was identified and rated by an optical density (DO) analysis, standardized by a 0 to 255 gray scale, where " 0 " indicated the absence of pigments (black).

\section{Statistical analysis}

Kolmogorov-Smirnov with Dallal-Wilkinson-Lilliefors significance and Mann-Whitney non-parametric test were performed, using GraphPad Prism 5 (GraphPad Software Inc., San Diego, CA, USA). Every " $p$ " value less than 0.05 was considered statistically significant.

\section{Results}

This study evaluated 20 samples collected from 13 older dogs, with an average age of 9.4 years, of different breeds (three mixed-breed dogs, two Poodles, two Schnauzers, one Labrador, one Maltese, one Beagle, one Pointer, one West Highland White Terrier and one Yorkshire Terrier), divided into two groups: DC group included eight dogs (seven females and one male) and the HC group with five dogs (four females and one male).

Every studied diabetic $\operatorname{dog}$ (DC) suffered from suddenly acquired, bilateral, complete and intumescent cataracts. Dogs of the HC group had hypermature cataracts on the studied eye, but cataracts at various stages on the other eye, such as: none $(n=2)$, immature $(n=2)$ and incipient $(n=1)$.

Table 1 - Distribution of obtained values for Caspase- 3 and Beclin-1 expression, in dogs with hypermature and diabetic cataracts, which were submitted to $0.1 \%$ trypan blue stain during Phaco - São Paulo, Brazil - 2015

\begin{tabular}{|c|c|c|c|c|c|c|}
\hline Cell death markers & Groups & Minimum & Median & Maximum & Standard Error & $P<0.05$ \\
\hline \multirow{2}{*}{ Caspase-3 } & $D C^{*}$ & 0.39 & 0.52 & 0.58 & 0.04 & \multirow{2}{*}{$P=0.22$} \\
\hline & $\mathrm{HC}+$ & 0.32 & 0.38 & 0.56 & 0.04 & \\
\hline \multirow{2}{*}{ Beclin-1 } & $\mathrm{DC}^{*}$ & 3.61 & 16.60 & 35.22 & 5.61 & \multirow{2}{*}{$P=0.67$} \\
\hline & $\mathrm{HC} \dagger$ & 2.08 & 11.28 & 51.24 & 8.84 & \\
\hline
\end{tabular}

${ }^{\star} \mathrm{DC}=$ Dogs with diabetic cataracts submitted to $0.1 \%$ trypan blue staining

$\dagger \mathrm{HC}=$ Dogs with hypermature cataracts submitted to $0.1 \%$ trypan blue stainin 


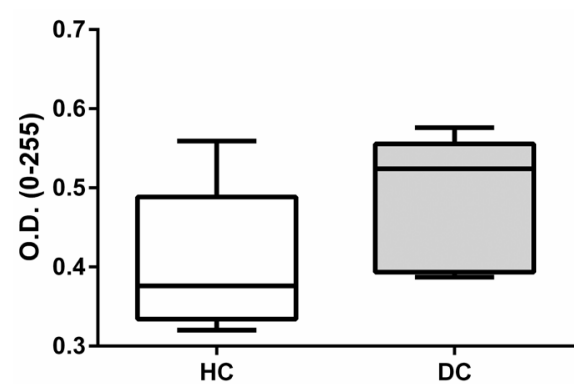

Figure 1 - Graphical representation of the results obtained from optical density (D.O.) analysis for caspase-3 in HC and DC groups

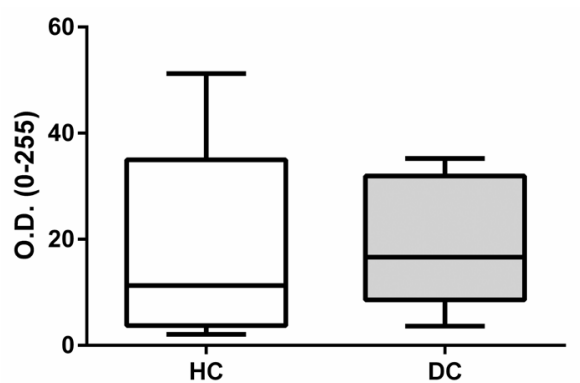

Figure 2 - Graphical representation of the results obtained from optical density (D.O.) analysis for beclin-1 in HC and DC groups

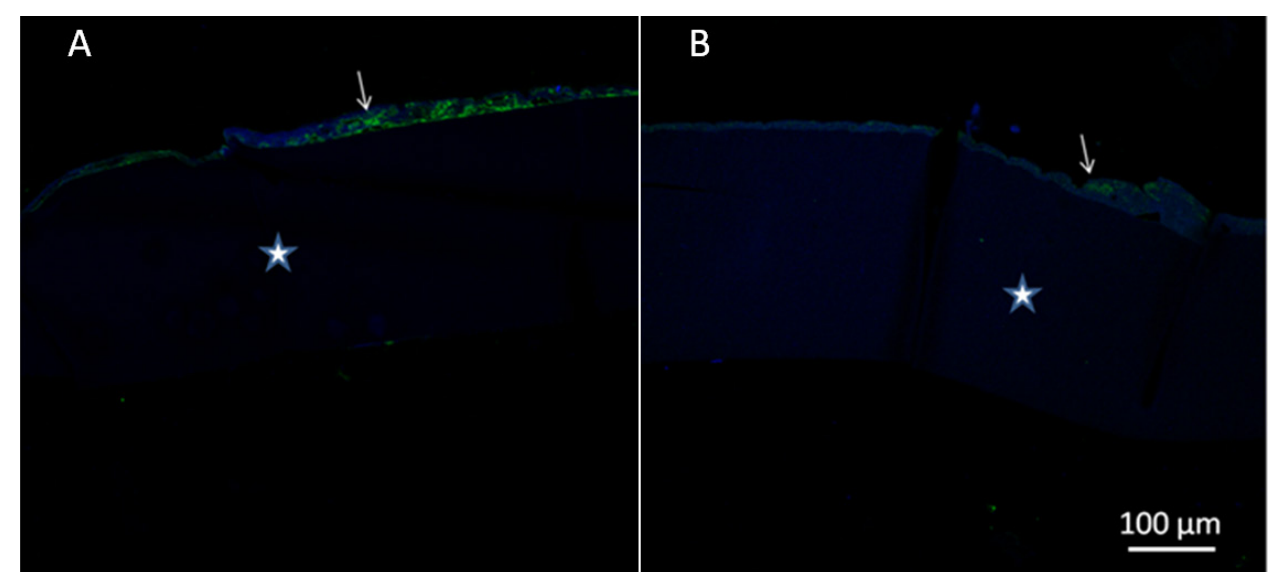

Figure 3 - Confocal laser scanning photomicrographs showing molecular expression of caspase-3 (in green) on LECs (white arrow) of $A$ : Mixed breed, 12 y.o. female dog (HC group) and $B$ : Mixed breed, 12 y.o. female dog (DC group). The lens anterior capsule in each sample is marked by a white star (original magnification x100)
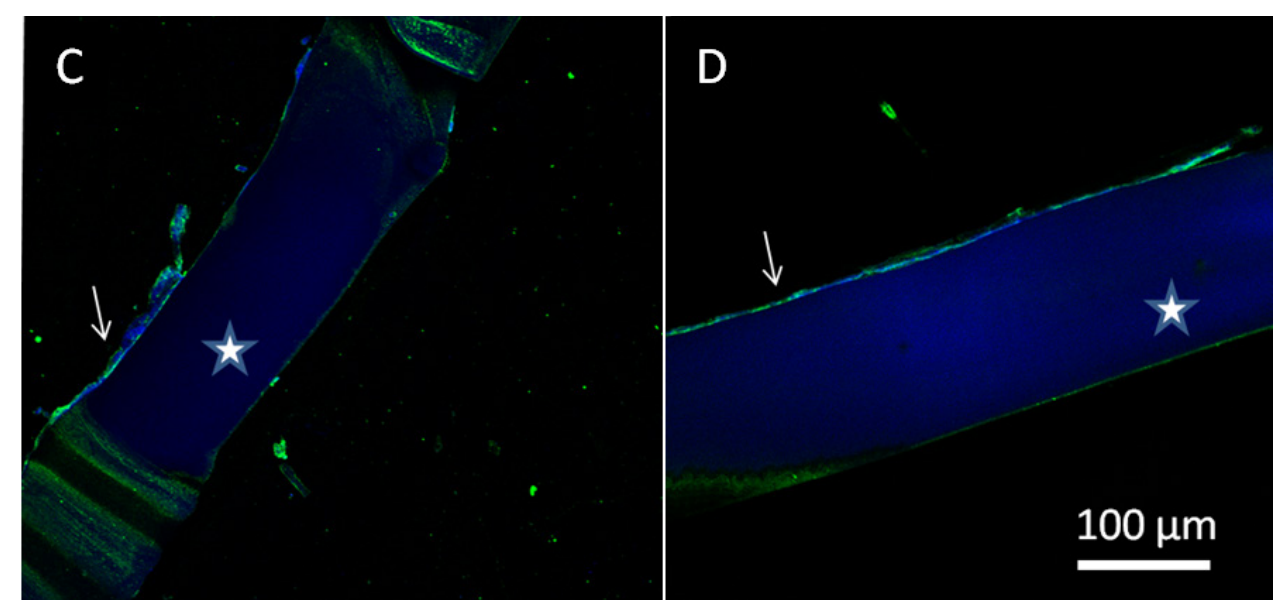

Figure 4 - Confocal laser scanning photomicrographs showing molecular expression of beclin-1 (in green) on LECs (white arrow) in C: Yorkshire, 10 y.o. female dog (HC group) and D: Beagle, 8 y.o. female dog (DC group). The lens anterior capsule in each sample is marked by a white star (original magnification x100)

Immunofluorescence DO analysis for caspase-3 and beclin-1 expression in LECs was performed in five randomly chosen samples of each group. Programmed cell death (apoptosis and autophagy) occurred in both groups, without statistically significant differences between them (Table 1, Figures 1 and 2). Confocal laser scanning photomicrographs are shown in figure 3 for caspase- 3 and figure 4 for beclin-1.

\section{Discussion}

Two completely distinct types of cataracts were studied: the bilateral and intumescent diabetic cataract of sudden onset (BASHER; ROBERTS, 1995; BEAM et al., 1999) and the evolved, chronic and slow-progression hypermature cataract (SLATTER, 2005; OFRI, 2008). We chose to evaluate LECs from these cataract types because they are frequently diagnosed at the Veterinary Hospital of 
the Faculty of Veterinary Medicine and Animal Science, University of São Paulo (HOVET-FMVZ-USP) in Brazil where this study was conducted. However, restricting the study to older and diabetic dogs with aggressive and high-risk cataracts, which could be safely submitted to a Phaco surgery, required our special attention to exclusion criteria, as these health conditions could make animals more susceptible to other systemic and ophthalmic diseases (BASHER; ROBERTS, 1995; LEASURE et al., 2001; LANDRY et al., 2004) capable of compromising surgical success and/or the collection of samples. Our strict inclusion criteria not only increased the difficulty of enrolling animals into the study, but also, and more importantly, of recruiting a sufficient number of samples for statistical analysis.

Expression of caspase- 3 and beclin- 1 was observed in every sample of the study. The obtained results are like those in other studies that demonstrated the presence of programmed cell death by apoptosis and the higher expression of caspase-3 in LECs, induced by oxidative stress of the advanced age and diabetic cataracts in humans (KIM et al., 2012; JUNG et al., 2013).

Only a few studies have evaluated the expression of molecular markers for autophagy in LECs from several types of cataracts. Autophagy is a process by which eukaryotic cells regulate the turnover of long-lived proteins and cytoplasmic organelles. It occurs in all cells performing homeostatic function and acts as a catabolic adaptive process in response to different forms of stress (CAO; KLIONSKY, 2007; FROST et al., 2014). This was evident in all the studied samples, suggesting that despite the difference in pathophysiology, beclin-1 signaling in LECs of older dogs is present in diabetic and hypermature cataracts after Phaco with $0.1 \%$ TB stain.

In the present investigation study, there was no evidence of the potential toxicity by trypan blue staining (PORTES et al., 2007, 2010). Previous studies that reported statistically significant different cell death rates by apoptosis and autophagy when comparing stained and unstained samples were performed only in LECs collected from nuclear and subcapsular cataracts of healthy old people (PORTES et al., 2010). We evaluated LECs of a different species (older dogs, healthy as well as diabetics), with complete cataracts (diabetic and hypermature) and all of them were submitted to the stain. As only aggressive and high-risk cataracts were studied, it is possible to suggest that these tissues must already have been expressing most of their signaling molecules before its exposure to the stain, and the use of TB must have also cooperated to induce cellular death processes, but in a minor way.

PCO occurs mainly due to proliferation, migration and epithelial to mesenchymal transition of residual LECs that are left in the capsular bag after irrigation and aspiration of the lens cortex (GLOVER; CONSTANTINESCU, 1997; BRAS et al., 2006; POT et al., 2009; WORMSTONE et al., 2009; JOSHI, 2013) and/ or by surgical trauma itself (WORMSTONE et al., 2009) and the use of TB stain (PORTES et al., 2007, 2010). Since we found that every studied LEC expressed some degree of apoptosis and autophagy, the obtained results may suggest the adoption of an additional approach to the study of PCO formation in dogs with cataracts after Phaco utilizing $0.1 \% \mathrm{~TB}$.

\section{Conclusion}

Obtained results suggest that metabolism of diabetes, the chronic hypermature cataract and/or the use of $0.1 \%$ TB stain appears to induce significant stress to LECs of older dogs submitted to Phaco. This finding may be helpful to future studies of posterior lens capsule opacity after surgery. Moreover, authors suggest other studies with stained and unstained samples, be collected from dogs of different ages presenting none and other different types of cataracts.

\section{Acknowledgements}

The authors thank Thayane Gomes for technical assistance. Supported in part by the CNPq (National Counsel of Technological and Scientific Development).

BAGLEY II, L. H.; LAVACH, J. D. Comparison of postoperative phacoemulsification results in dogs with and without diabetes mellitus: 153 cases (1991-1992). Journal of the American Veterinary Medical Association, v. 205, n. 8, p. 1165-1169, 1994. 
BASHER, A. W. P.; ROBERTS, S. M. Ocular manifestations of diabetes mellitus: diabetic cataracts in dogs. Veterinary Clinics of North America: Small Animal Practice, v. 25, n. 3, p. 661-676, 1995. doi: 10.1016/S0195-5616(95)50061-0.

BEAM, S.; CORREA, M. T.; DAVIDSON, M. G. A retrospective-cohort study on the development of cataracts in dogs with diabetes mellitus: 200 cases. Veterinary Ophthalmology, v. 2, n. 3, p. 169-172, 1999. doi: 10.1046/j.1463-5224.1999.00073.x.

BRAS, I. D.; COLITZ, C. M. H.; SAVILlE, W. J. A.; GEMENSKY-METZLER, A. J.; WILKIE, D. A. Posterior capsular opacification in diabetic and non diabetic canine patients following cataract surgery. Veterinary Ophthalmology, v. 9, n. 5, p. 317-327, 2006. doi: 10.1111/j.1463-5224.2006.00458.x.

CAO, Y.; KLIONSKY, D. J. Physiological functions of Atg6/Beclin 1: a unique autophagy-related protein. Cell Research, v. 17, p. 839-849, 2007. doi: 10.1038/cr.2007.78.

CHANG, Y. S.; TSENG, S. Y.; TSENG, S. H.; CHEN, Y. T.; HSIAO, J. H. Comparison of dyes for cataract surgery. Part 1: cytotoxicity to corneal endothelial cells in a rabbit model. Journal of Cataract \& Refractive Surgery, v. 31, n. 4, p. 792-798, 2005. doi: 10.1016/j.jcrs.2004.07.020.

DICK, H. B.; ALIYEVA, S. E.; HENGERER, F. Effect of trypan blue on the elasticity of the human anterior lens capsule. Journal of Cataract \& Refractive Surgery, v. 34, n. 8, p. 1367-1373, 2008. doi: 10.1016/j.jcrs.2008.03.041.

FROST, L. S.; MITCHELL, C. H.; BOESZE-BATTAGLIA, K. Autophagy in the eye: implications for ocular cell health. Experimental Eye Research, v. 124, p. 56-66, 2014. doi: 10.1016/j.exer.2014.04.010.

GELATT, K. N.; GELATT, J. P. Surgical procedures of the lens and cataracts, In: GELATT, K. N.; GELATT, J. P. (Eds.). Small animal ophthalmic surgery: a practical guide for the practicing veterinarian. Gainesville: Elsevier Health Sciences, 2001. p. 305-355.

GLOVER, T. D.; CONSTANTINESCU, G. M. Surgery for cataracts. Veterinary Clinics of North America: Small
Animal Practice, v. 27, n. 5, p. 1143-1173, 1997. doi: 10.1016/ S0195-5616(97)50107-0.

JOSHI, R. S. Primary posterior capsular opacification in Indian rural population undergoing cataract surgery for hypermature senile cataract. Clinical Ophthalmology, v. 7, p. 1605-1608, 2013. doi: 10.2147/OPTH.S49396.

JUNG, Y.; KIM, M. S.; JOO, C. K.; CHUNG, S. K. Role of intrinsic apoptotic pathway in cataractogenesis in type 2 diabetic patients. Journal of Cataract \& Refractive Surgery, v. 39, n. 10, p. 1470-1476, 2013. doi: 10.1016/j.jcrs.2013.03.036.

KHANNA, R.; PUJARI, S.; SANGWAN, V. Cataract surgery in developing countries. Current Opinion in Ophthalmology, v. 22, n. 1, p. 10-14, 2011. doi: 10.1097/ ICU.0b013e3283414f50.

KIM, B.; KIM, S. Y.; CHUNG, S. K. Changes in apoptosis factors in lens epithelial cells of cataract patients with diabetes mellitus. Journal of Cataract \& Refractive Surgery, v. 38, n. 8, p. 1376-1381, 2012. doi: 10.1016/j. jcrs.2012.04.026.

KODJIKIAN, L.; RICHTER, T.; HALBERSTADT, M.; BEBY, F.; FLUECKIGER, F.; BOEHNKE, M.; GARWEG, J. G. Toxic effects of indocyanine green, infracyanine green, and trypan blue on the human retinal pigmented epithelium. Graefe's Archive for Clinical and Experimental Ophthalmology, v. 243, n. 9, p. 917-925, 2005. doi: 10.1007/s00417-004-1121-6.

LANDRY, M. P.; HERRING, I. P.; PANCIERA, D. L. Funduscopic findings following cataract extraction by means of phacoemulsification in diabetic dogs: 52 cases (1993-2003). Journal of the American Veterinary Medical Association, v. 225, n. 5, p. 709-716, 2004. doi: 10.2460/ javma.2004.225.709.

LEASURE, J.; GELATT, K. N.; MACKAY, E. O. The relationship of cataract maturity to intraocular pressure in dogs. Veterinary Ophthalmology, v. 4, n. 4, p. 273-276, 2001. doi: 10.1046/j.1463-5216.2001.00199.x.

NANAVATY, M. A.; JOHAR, K.; SIVASANKARAN, M. A.; VASAVADA, A. R.; PRAVEEN, M. R.; ZETTERSTRÖM, C. Effect of trypan blue staining on the density and 
viability of lens epithelial cells in white cataract. Journal of Cataract \& Refractive Surgery, v. 32, n. 9, p. 1483-1488, 2006. doi: 10.1016/j.jcrs.2006.04.017.

OFRI, R. Lens. In: MAGGS, D. J.; MILLER, P. E.; OFRI, R. I. (Eds.). Slatter's fundamentals of veterinary ophthalmology. 4th ed. St. Louis: Saunders Elsevier, 2008. p. 258-276.

OZTURK, F.; OSHER, R. H. Capsular staining: recent developments. Current Opinion in Ophthalmology, v. 17, n. 1, p. 42-44, 2006. doi: 10.1097/01.icu.0000193066.09499.a5.

PORTES, A. L. F.; ALMEIDA, A. C.; ALlODI, S.; MONTEIRO, M. L. R.; MIGUEL, N. C. O. Trypan blue staining for capsulorhexis: ultrastructural effect on lens epithelial cells and capsules. Journal of Cataract \& Refractive Surgery, v. 36, n. 4, p. 582-587, 2010. doi: 10.1016/j.jcrs.2009.11.005.

PORTES, A. L. F.; MONTEIRO, M. L. R.; ALLODI, S.; MIGUEL, N. C. O. Effect of trypan blue on lens epithelial cells in human eyes having capsulorhexis. Journal of Cataract \& Refractive Surgery, v. 33, n. 6, p. 1135-1136, 2007. doi: 10.1016/j.jcrs.2007.02.038.

POT, S. A.; CHANDLER, H. L.; COLITZ, C. M. H.; BENTLEY, E.; DUBIELZIG, R. R.; MOSLEY, T. S.; REID, T. W.; MURPHY, C. J. Selenium functionalized intraocular lenses inhibit posterior opacification in an ex vivo canine lens capsular bag assay. Experimental Eye Research, v. 89, n. 5, p. 728-734, 2009. doi: 10.1016/j.exer.2009.06.016.
SIGLE, K. J.; NASISSE, M. P. Long-term complications after phacoemulsification for cataract removal in dogs: 172 cases (1995-2002). Journal of the American Veterinary Medical Association, v. 228, n. 1, p. 74-79, 2006. doi: 10.2460/javma.228.1.74.

SLATTER, D. Fundamentos de oftalmologia veterinária. 3. ed. São Paulo: Roca, 2005. 686 p.

TIWARI, A.; RAM, J.; LUTHRA-GUPTASARMA, $M$. Targeting the fibronectin type III in Tenascin-C inhibits epithelial mesenchymal transition in the context of Posterior Capsular Opacification. Investigative Ophthalmology \& Visual Science, v. 56, n. 1, p. 272-283, 2015. doi: 10.1167/iovs.14-14934.

VENKATESH, R.; TAN, C. S. H.; SENGUPTA, S.; RAVINDRAN, R. D.; KRISHNAN, K. T.; CHANG, D. F. Phacoemulsification versus manual small-incision cataract surgery for white cataract. Journal of Cataract \& Refractive Surgery, v. 36, n. 11, p. 1849-1854, 2010. doi: 10.1016/j.jcrs.2010.05.025.

WOLLENSAK, G.; SPÖRL, E.; PHAM, D. T. Biomechanical changes in the anterior lens capsule after trypan blue staining. Journal of Cataract \& Refractive Surgery, v. 30 , n. 7, p. 1526-1530, 2004. doi: 10.1016/j. jcrs.2003.11.031.

WORMSTONE, I. M.; WANG, L.; LIU, C. S. C. Posterior capsule opacification. Experimental Eye Research, v. 88, n. 2, p. 257-269, 2009. doi: 10.1016/j.exer.2008.10.016. 